\title{
Modulation of Pathogenesis by Intestinal Microflora: The Role of Helicobacter pylori in Gastroduodenal Ulcer and Gastric Cancer
}

\author{
Noritoshi Tanida, Takashi Sakagami, Yoshihiro Fukuda and Takashi Shimoyama \\ Department of Internal Medicine 4, Hyogo College of Medicine, 1-1 Mukogawacho, Nishinomiya, Hyogo 663-8501, Japan \\ Received for publication, July 1, 1998
}

\begin{abstract}
Helicobacter pylori shows a highly diverse nature in all aspects, from gene profiles to biological features. Interaction between $\boldsymbol{H}$. pylori and host cells is also complex. These characteristics of $\boldsymbol{H}$. pylori may explain some conflicting results regarding the pathogenicity of $\boldsymbol{H}$. pylori in human diseases. Not all strains are pathogenic, as exemplified by Type I and Type II strains. This may possibly lead to the development of a live vaccine using non-toxic strains against toxic strains. To achieve this goal, further study is necessary to elucidate the exact role of $\boldsymbol{H}$. pylori in gastroduodenal diseases.
\end{abstract}

Key words: Helicobacter pylori; gastric microflora; gastritis; peptic ulcer; gastric cancer

\section{HELICOBACTER PYLORI AS A MEMBER OF GASTRIC MICROFLORA}

Gastric microflora. The human stomach has been thought to be sterile because of its strongly acidic environment. Microflora can be colonized when acid secretion is ceased or decreased. For example, gastric surgery results in the deprivation of acid-secreting cells together with an alteration of the anatomical structure. Similar environmental change occurs when gastric acid secretion is suppressed by $\mathrm{H}_{2}$-receptor antagonists or proton pump inhibitors. These environmental changes of the stomach lead to comfortable conditions for infestation by microorganisms $(1,29)$.

Under normal strong acidity, the infestation of microorganisms is below $10^{5}$ colony-forming units (CFU)/ $\mathrm{ml}$ in the stomach. Many of these are opportunistic organisms, though they may be implicated in post-operative sepsis in some cases (63). When gastric acidity decreases, infestation level increases above $10^{5} \mathrm{CFU} /$ $\mathrm{ml}(1)$. These organisms are members of gut microflora, and their infestation may induce bacterial overgrowth syndrome or malnutrition status (1).

Spiral microorganisms in the stomach. The presence of spiral bacteria in the stomach was known more than 100 years ago (64). Although several researchers described spiral organisms in the human stomach $(13$, $22,65)$, their presence had been ignored until recent rediscovery by Warren and Marshall in $1983(39,72)$.

Human gastric microflora are summarized in Table 1 together with $H$. pylori (26). Under ordinary conditions, $H$. pylori is a dominant species in the stomach. $H$. pylori is characterized as mucosa-associated bacte- ria, whereas other bacteria are found in gastric contents. These findings indicate that $H$. pylori is indeed a member of gastric microflora and other bacteria are opportunistic. Thus, $H$. pylori may exert certain actions on the gastric mucosa, whereas other bacteria may exert their actions only when an abnormal condition is induced in the stomach through environmental changes.

Helicobacter pylori. Genus Helicobacter includes several gastric and non-gastric species (21). H. pylori is a spiral, slightly curved Gram-negative rod with 2 to 7 unipolar flagella. Natural infestation of $H$. pylori is confined to the human and non-human primate stomach. The bacterium possesses urease, and is thereby able to catalyze urea to ammonia and carbon dioxide. The bacterium itself is acid-sensitive, but because of this ammonia production, it can survive under strong acidic conditions (14).

Several factors in addition to ammonia production enable $H$. pylori to colonize in the stomach. Unipolar flagella can expel the bacterium rapidly into the mucous layer, thus avoiding longer exposure in the acidic lumen. Without this mobility the bacterium could not colonize in the stomach (15). Adherence to the epithelium involves binding to Lewis ${ }^{b}$ blood group antigens (4), which is thought to be one of the reasons for the host preference of $H$. pylori. This adherence phenomenon is also the first step of pathogenesis of $H$. pylori to the human stomach.

Pathogenesis of H. pylori. H. pylori exerts a variety of pathogenic actions on the gastric mucosa and induces inflammatory response and epithelial cell damage (Fig. 1). Factors involved in these mechanisms include enzymes, toxins, structure substance such as li- 
Table 1. Gastric microflora of patients with gastroduodenal diseases with respect to the $\mathrm{pH}$ of gastric contents.

\begin{tabular}{|c|c|c|c|c|c|c|}
\hline & \multicolumn{2}{|c|}{$\mathrm{pH}<3 \quad(n=20)$} & \multicolumn{2}{|c|}{$3<\mathrm{pH}<6 \quad(n=18)$} & \multicolumn{2}{|c|}{$\mathrm{pH}>6 \quad(n=18)$} \\
\hline & $\begin{array}{l}\text { Detected } \\
\text { cases }\end{array}$ & $\begin{array}{l}\text { Count of } \\
\text { organisms }\end{array}$ & $\begin{array}{c}\text { Detected } \\
\text { cases }\end{array}$ & $\begin{array}{l}\text { Count of } \\
\text { organisms }\end{array}$ & $\begin{array}{c}\text { Detected } \\
\text { cases }\end{array}$ & $\begin{array}{l}\text { Count of } \\
\text { organisms }\end{array}$ \\
\hline Facultative anaerobes & $8(40)$ & $2.4 \pm 1.3$ & $14(78)$ & $6.2 \pm 0.6$ & $18(100)$ & $5.5 \pm 1.0$ \\
\hline Enterobacteriaceae & 0 & - & $6(33)$ & $5.9 \pm 0.6$ & $5(28)$ & $4.4 \pm 1.3$ \\
\hline Streptococci & $2(10)$ & $2.7 \pm 0.2$ & $13(72)$ & $6.2 \pm 0.6$ & $16(89)$ & $5.3 \pm 0.9$ \\
\hline Micrococcaceae & $2(10)$ & $1.5 \pm 0.9$ & $4(22)$ & $3.0 \pm 0.7$ & $4(22)$ & $4.8 \pm 1.7$ \\
\hline Yeasts & $6(30)$ & $2.1 \pm 1.3$ & $2(11)$ & $3.5 \pm 1.0$ & $3(17)$ & $4.8 \pm 2.0$ \\
\hline Bacilli & $2(10)$ & $3.7 \pm 1.1$ & $1(6)$ & 4.0 & 0 & - \\
\hline Lactobacilli & $2(10)$ & $2.8 \pm 0.5$ & $8(44)$ & $4.5 \pm 0.5$ & $9(50)$ & $3.6 \pm 0.7$ \\
\hline Obligate anaerobes & 0 & - & $9(50)$ & $4.8 \pm 1.2$ & $10(56)$ & $4.0 \pm 1.4$ \\
\hline Bifidobacteria & 0 & 一 & $4(22)$ & $4.6 \pm 1.0$ & $5(28)$ & $3.1 \pm 0.9$ \\
\hline Eubacteria & 0 & - & $1(6)$ & 2.6 & $1(6)$ & 3.2 \\
\hline Bacteroidaceae & 0 & 一 & $5(28)$ & $3.7 \pm 0.7$ & $2(11)$ & $4.3 \pm 0.9$ \\
\hline Peptococcaceae & 0 & - & $3(17)$ & $6.1 \pm 0.5$ & $4(22)$ & $4.9 \pm 1.1$ \\
\hline Clostridia & 0 & - & 0 & - & $1(6)$ & 3.5 \\
\hline Helicobacter pylori & $12(60)$ & $5.1 \pm 1.2$ & $11(61)$ & $6.1 \pm 1.0$ & $14(78)$ & $5.9 \pm 1.4$ \\
\hline Total & $14(70)$ & $5.3 \pm 1.3$ & $13(72)$ & $6.6 \pm 0.6$ & $18(100)$ & $6.1 \pm 1.3$ \\
\hline
\end{tabular}

Results are shown by number of detected cases with \% in parentheses, and counts of organisms are mean \pm SD (log/ml) among detected cases.

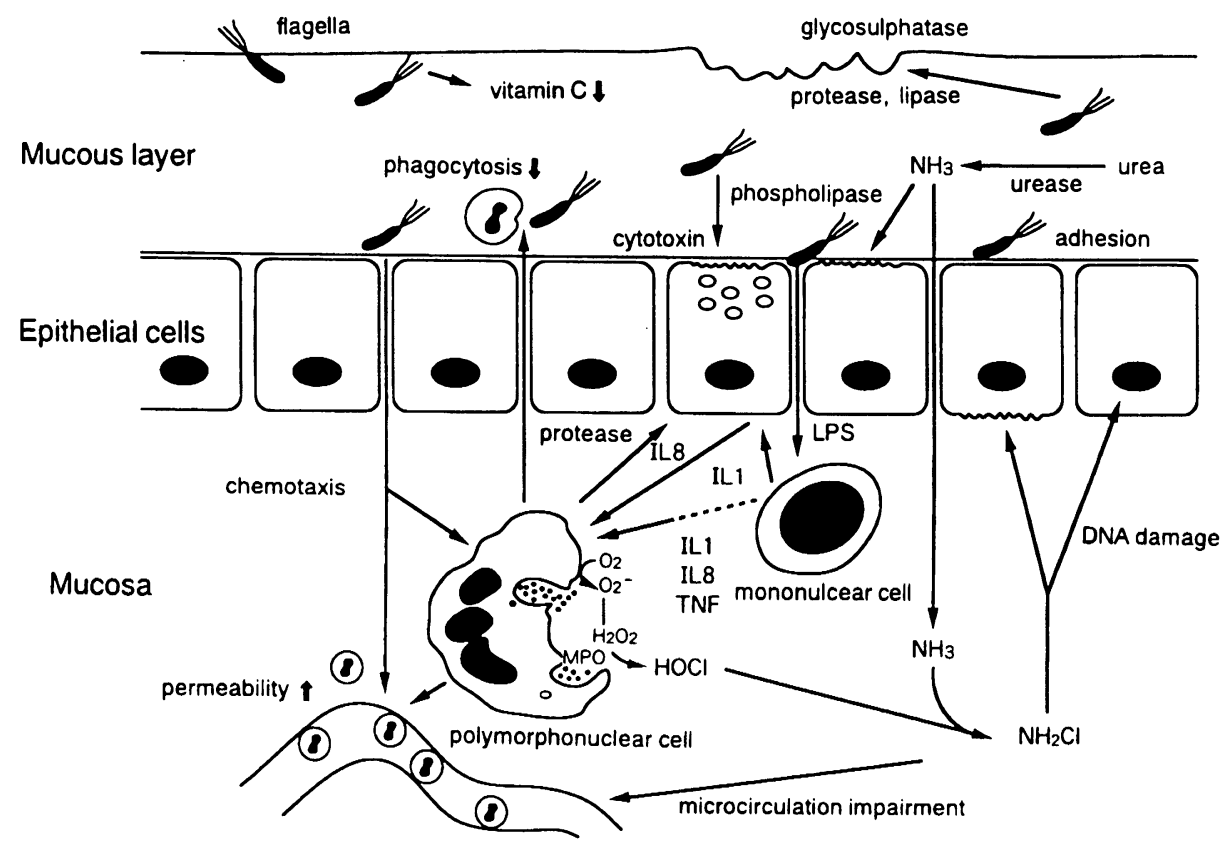

Fig. 1. An overview of the pathogenesis of H. pylori. LPS, lipopolysaccharide; IL, interleukin; TNF, tumor necrosis factor; MPO, myeloperoxidase.

popolysaccharide (LPS) and heat-shock proteins (Hsp).

Enzymes secreted by the bacterium include urease, glycosulfatase, phospholipase and others. Ammonia produced by urease directly damages gastric epithelial cells (47). Glycosulfatase may disturb the mucous layer of the stomach and decrease the protective role of the mucous layer against acid (43). Phospholipase can cleavage membrane phospholipids and damage the membrane structure of gastric epithelial cells (11).

H. pylori produces toxins. More than $50 \%$ of the 
strains have toxin inducing vacuolization of epithelial cells (20). Strains which produce this toxin (VacA) are designated as Type I. In general, Type I strains are associated with more severe pathogenicity on the gastric mucosa than Type II strains, which do not have VacA $(9,38)$. Cytotoxin-associated gene A, cagA, is found in almost all VacA-positive strains. Later, the cag pathogenicity island was identified and its role in virulence was assessed (6). Mutants of cag showed a reduction of interleukin-8 secretion from gastric epithelial cells (61). Thus, cag is involved in $H$. pylori-host cell interaction and associated with the chronic inflammatory reaction of the gastric mucosa induced by $H$. pylori.

Hsps or chaperonins are highly immunogenic. Because of this property, some role of Hsps is speculated in the immune system (49), although there is no association between Hsps and disease. Experimentally, atrophic gastritis is induced in the LPS-sensitive strain but not in the LPS-insensitive strains of mice (59). The induction of mononuclear cells to LPS-sensitive mice indicated that LPS induced an inflammatory response through cellular immune response (59).

The toxicity of the LPS of $H$. pylori itself is lower compared with that of other bacteria (45). This finding is ascertained by the characteristic of Lipid A, a component of LPS, of $H$. pylori. The induction of interleukin- 8 and tumor necrosis factor-alpha from fibroblasts is lower, while the induction of interleukin6 and natural killer cell activity is comparable to that of Escherichia coli-Lipid A (28). These results suggest that the biological activity of $H$. pylori-LPS is relatively low, while its immunogenicity is maintained.

$H$. pylori infection increases pro-inflammatory cytokines (10). Among them, interleukin-8, which is secreted by gastric epithelial cells, is an important host mediator for neutrophil migration and activation (10). Neutrophil activation and the production of reactive oxygen metabolites cause mucosal injury $(46,66)$. The active components of $H$. pylori mentioned earlier play a role in these inflammatory responses and interactions between $H$. pylori and host cells. Also, the degree of these changes and mucosal injury is more severe in Type I than Type II strains.

These characteristics of $H$. pylori suggest that this bacterium is pathogenic. However, H. pylori may play a protective role under certain conditions (35). Therefore, whether $H$. pylori is commensal or pathogenic in the stomach is not a simple issue.

H. pylori-induced gastritis. Pathogenicity of H. pylori eventually induces gastritis. Indeed, $H$. pylori is a major cause of human gastritis. Originally, $H$. pylori was found from the gastric mucosa with chronic inflammation $(39,72)$. A challenge of $H$. pylori (i.e., ingestion of $H$. pylori) by previously $H$. pylori-negative volunteers resulted in histological and clinical gastritis $(40,44) . H$. pylori is detected in more than $85 \%$ of the patients with chronic inflammation of the gastric mucosa including polymorphonuclear and mononuclear cells. Eradication of $H$. pylori results in the regression of these cell infiltrations (56).

When infestation of $H$. pylori persists, a significant proportion of non-atrophic gastritis progresses to atrophic gastritis (33): the rate of transition from non-atrophic to atrophic gastritis was estimated to be 2.1 to $2.6 \%$ per year for $H$. pylori-positive patients (71). The severity and density of $H$. pylori infestation vary depending on different diseases. Thus, gastritis is generally restricted in the antral region in patients with duodenal ulcer, whereas gastritis in gastric ulcer and cancer patients is distributed more widely in the body of the stomach (37).

\section{H. PYLORI AND PEPTIC ULCER}

H. pylori in peptic ulcer. H. pylori has been found more frequently in patients with gastroduodenal ulcer than healthy subjects. The age of $H$. pylori infection is thought to be important in the development of gastric and duodenal ulcers. Namely, an earlier establishment of $H$. pylori infection is a risk factor for gastric ulcer but not duodenal ulcer (2). However, an Indian experience, i.e., high prevalence rate of $H$. pylori in younger age groups and duodenal ulcer, is not in accord with this theory.

The evidence of a relationship between $H$. pylori and peptic ulcer has emerged from clinical experience. The recurrence rate of peptic ulcer is quite high, whereas the eradication of $H$. pylori completely prevents ulcer recurrence (25). Although many studies including ours (Fig. 2) do not concur with the complete prevention of ulcer recurrence (24), there is no doubt that $H$. pylori is a risk factor for ulcerogenesis.

Mechanism of ulcer formation by $H$. pylori. Factors involved in mucosal injury and the induction of gastritis are likely to be contributory to ulcerogenesis as well. For example, ammonia produced by $H$. pylori induces gastric ulcer experimentally (47). Gastric metaplasia harboring $H$. pylori occur in the duodenal bulb (75), which may directly damage duodenal mucosa. However, these findings have offered little evidence regarding the exact mechanism of $H$. pylori-related ulcer formation in humans.

H. pylori colonizes mostly in the antrum of patients 
(\%)

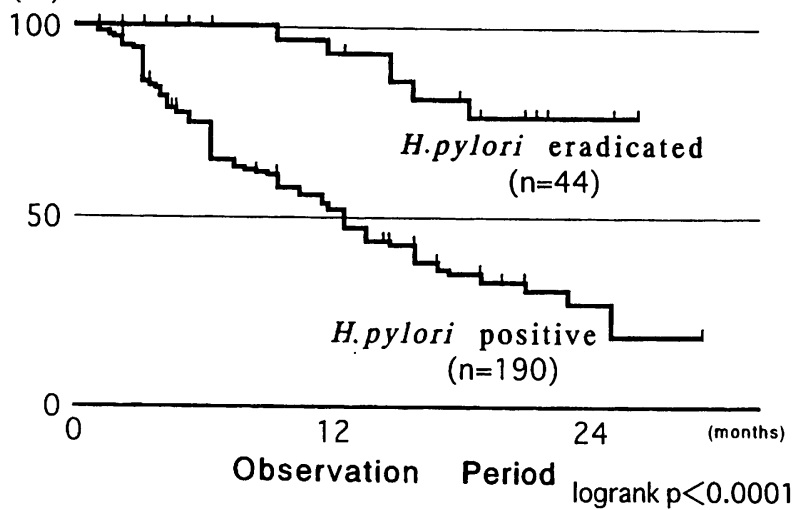

Fig. 2. Cumulative non-recurrence rate of gastric ulcer with respect to eradication of $H$. pylori.

with duodenal ulcers (37). Local acid secretion and colonization of $H$. pylori are closely associated (12). H. pylori infection blocks the physiological inhibitory effect of gastric acid secretion induced by antral distension, which results in an increased duodenal acid load (5I). This abnormal response is restored by the eradication of $H$. pylori (5I). This acid hypersecretion and mucosal damage caused by $H$. pylori are critically important factors contributing to ulcer formation.

Management of gastroduodenal diseases. Although there are unsolved questions regarding the role of $H$. pylori in peptic ulcer, the eradication of $H$. pylori is likely to be a reasonable option for the management of peptic ulcer. Thus, consensus guidelines have been reported at conferences worldwide $(16,36,48)$.

These conferences discussed the role of $H$. pylori and implications of its eradication in gastroduodenal diseases. Although there are small differences among the 3 guidelines, they unanimously recommend that ulcer patients with $H$. pylori infection receive eradication therapy whether the ulcer is active or in remission.

In recommendable regimens, above $80 \%$, preferably over $90 \%$ eradication is necessary. At present, the combination of a proton pump inhibitor and 2 antibiotics have offered a satisfactory outcome (58).

\section{H. PYLORI IN GASTRIC CANCER}

Association of $H$. pylori and gastric cancer. The epidemiological findings of gastric cancer coincided with those of $H$. pylori. The carrying rate of $H$. pylori is high in Japanese (26) and in people with a high risk of gastric cancer (8). Epidemiological studies have confirmed the positive association of $H$. pylori infection and gastric carcinogenesis prospectively $(19,50$, 54). According to Parsonnet, $1 \%$ of $\mathrm{H}$. pylori-infected persons will eventually develop gastric cancer (52).

Additional findings. With regard to experimental findings, because of the lack of an adequate animal model for $\mathrm{H}$. pylori infestation, there is little evidence of the carcinogenic effect of $H$. pylori. In a rat MNNG model, the loading of $H$. pylori did not promote gastric carcinogenesis (30). A series of experimental studies were also inconclusive $(67,68)$.

The recent introduction of Mongolian gerbils to $H$. pylori experiments has given additional findings to this issue. Promoting and co-initiating effects were observed by $\mathrm{H}$. pylori infection in MNU-induced gastric carcinogenesis in these animals (41). More interestingly, a 62-week period of $H$. pylori infection resulted in the formation of adenocarcinomas in $37 \%$ of the infected animals (73). These results indicate that $H$. pylori has both initiating and promoting activity toward gastric carcinogenesis. Further study is needed to confirm these findings.

In a non-blinded study, the eradication of $H$. pylori resulted in the resolution of inflammation and intestinal metaplasia of the gastric mucosa and inhibited the development of new early gastric cancer (70). This finding should be examined in a blinded manner. Furthermore, the fundamental question, "What is early gastric cancer?," (17) must be settled before reaching any conclusion regarding this finding.

The role of $H$. pylori in gastric carcinogenesis. Based on epidemiological findings, $H$. pylori was defined as a "definite biological carcinogen" by WHO/ IARC in 1994 (27). H. pylori induces atrophic gastritis (33), and this effect is greater in cagA-positive than cagA-negative strains (32). Thus, the role of $H$. pylori in gastric carcinogenesis is thought to be indirect, i.e., the induction of atrophic gastritis as a first step in the gastritis-metaplasia-carcinoma sequence (7). A recent study on telomerase indicated that $H$. pylori was involved in metaplastic change (34), which may fill in the missing link for the role of $H$. pylori in the gastritismetaplasia-carcinogenesis sequence.

The direct involvement of $H$. pylori is also indicated by several studies including the latest reports, which showed the initiating and promoting activity of $H . p y$ lori in gastric carcinogenesis in Mongolian gerbils (41, 73). H. pylori causes neutrophil infiltration, and activated neutrophils induce DNA damage. Indeed, a parameter of DNA damage accumulated when $H$. pylori infected the stomach (18). A decrease in the level of vitamin $\mathrm{C}$ due to $H$. pylori infection may accelerate this process (57). Increased cell proliferation without a corresponding increase in apoptosis during the infection 
of $c a g A^{+}$strains may be a risk factor for the development of cancer from unlimited cell proliferation (55). Genetic abnormalities involving DCC and APC genes were described during transition from chronic gastritis to MALToma (5). Furthermore, ammonia, a product of $H$. pylori, promoted experimental gastric carcinogenesis (69).

Yet, several issues have been left to be solved regarding the carcinogenic role of $H$. pylori. The inverse relationship in epidemiological findings between gastric cancer and duodenal ulcer conflicts with the causal implication of $H$. pylori in gastric carcinogenesis. Further, $H$. pylori is not the sole factor for causing atrophic gastritis (60). Unlike MALToma (5), DCC, APC and other genes did not have any association with $H$. pylori infection (74). Unlike studies from Western countries $(19,50,54)$, epidemiological studies from countries with a high incidence of gastric cancer do not support the involvement of $H$. pylori in gastric carcinogenesis $(23,31)$. On the other hand, gastric carcinogenesis in younger age groups was likely to be affected by $H$. pylori infection $(3,23)$. The association of cagApositive strains and gastric cancer observed in Western countries (53) was not the case in Japan $(42,62)$.

Thus, the role of $H$. pylori in gastric carcinogenesis is likely to be different between countries with high and low incidences of gastric cancer. The action of $H$. pylori is probably dependent on stages of the gastritismetaplasia-carcinoma sequence. Also, host factors as well as other environmental factors may be important in the action of $H$. pylori in carcinogenesis.

\section{REFERENCES}

(1) Amano K. 1987. Relationship between microflora of the upper small intestine and steatorrhoea in patients with extensive gastric resection. Nippon Shokakibyo Gakkai Zasshi 84: 1591-1604.

(2) Blaser MJ, Chyou PH, Nomura A. 1995. Age at establishment of Helicobacter pylori infection and gastric carcinoma, gastric ulcer, and duodenal ulcer risk. Cancer Res 55: 562565.

(3) Blaser MJ, Perez-Perez GI, Kleanthous H, Cover TL, Peek RM, Chyou PH, Stemmermann GN, Nomure A. 1995. Infection with Helicobacter pylori strains possessing cagA is associated with an increased risk of developing adenocarcinoma of the stomach. Cancer Res 55: 2111-2115.

(4) Boren T, Falk P, Roth KA, Larson G, Normark S. 1993. Attachment of Helicobacter pylori to human gastric epithelium mediated by blood group antigens. Science 262: 1892-1895.

(5) Calvert R, Randerson J, Evans P, Cawkwell L, Lewis F, Dixon MF, Jack A, Owen R, Shiach C, Morgan GJ. 1995. Genetic abnormalities during transition from Helicobacter- pylori-associated gastritis to low-grade MALToma. Lancet 345: 26-27.

(6) Censini S, Lange C, Xiang Z, Crabtree JE, Ghiara P, Borodovsky M, Rappuoli R, Covacci A. 1996. cag, a pathogenicity island of Helicobacter pylori, encodes type Ispecific and disease-associated virulence factors. Proc Natl Acad Sci USA 93: 14648-14653.

(7) Correa P. 1992. Human gastric carcinogenesis: a multistep and multifactorial process. Cancer Res 52: 6735-6740.

(8) Correa P, Fox J, Fontham E, Ruiz B, Lin YP, Zavala D, Taylor N, Mackinley D, de Lima E, Portilla H, Zarama G. 1990. Helicobacter pylori and gastric carcinoma: serum antibody prevalence in populations with contrasting cancer risks. Cancer 66: 2569-2574.

(9) Covacci A, Censini S, Bugnoli M, Petracca R, Burroni D, Macchia G, Massone A, Papini E, Xiang Z, Figura N, Rappuoli R. 1993. Molecular characterization of the 128kDa immunodominant antigen of Helicobacter pylori associated with cytotoxicity and duodenal ulcer. Proc Natl Acad Sci USA 90: 5791-5795.

(10) Crabtree JE. 1996. Immune and inflammatory responses to Helicobacter pylori infection. Scand J Gastroenterol 215 (Suppl): 3-10.

(11) Daw MA, O'Moore R, O'Morain C. 1993. Detection of phospholipases and cytotoxic activities of Helicobacter pylori. In Helicobacter pylori and Gastroduodenal Pathology, Pajares JM, Pena AS, Malfertheiner P (eds), SpringerVerlag, Berlin, p. 101-106.

(12) Dixon MF. 1991. Helicobacter pylori and peptic-ulcerationhistopathological aspects. J Gastroenterol Hepatol 6: 125130.

(13) Doenges JL. 1938. Spirophetes in gastric glands of macacus, rhesus and humans without definite history of related disease. Proc Soc Exp Biol Med 38: 536-538.

(14) Eaton KA, Brooks CL, Morgan DR, Krakowka S. 1991. Essential role of urease in pathogenesis of gastritis induced by Helicobacter pylori in gnotobiotic piglets. Infect Immun 59: 2470-2475.

(15) Eaton KA, Suerbaum S, Josenhans C, Krakowka S. 1996. Colonization of gnotobiotic piglets by Helicobacter pylori deficient in two flagellin genes. Infect Immun 64: 24452448.

(16) The European Helicobacter pylori Study Group. 1997. Current European concepts in the management of Helicobacter pylori infection. The Maastricht Consensus Report. Gut 41: 8-13.

(17) Everett SM, Axon ATR. 1998. Early gastric cancer: disease or pseudo-disease? Lancet 351: 1350-1352.

(18) Farinati F, Cardin R, Degan P, Rugge M, Mario FD, Bonvicini P, Naccarato R. 1998. Oxidative DNA damage accumulation in gastric carcinogenesis. Gut 42: 351-356.

(19) Forman D, Newell DG, Fullerton F, Yarnell JW, Stacey AR, Wald N, Sitas F. 1991. Association between infection with Helicobacter pylori and risk of gastric cancer: evidence from a prospective investigation. Br Med J 302: 1302-1305.

(20) Fox JG, Correa P, Taylor NS, Thompson N, Fontham E, Janney F, Sobhan M, Ruiz B, Hunter F. 1992. High preva- 
lence and persistence of cytotoxin-positive Helicobacter pylori strains in a population with high prevalence of atrophic gastritis. Am J Gastroenterol 87: 1554-1560.

(21) Fox JG, Lee A. 1997. The role of Helicobacter species in newly recognized gastrointestinal tract diseases of animals. Lab Anim Sci 47: 222-255.

(22) Freedburg AS, Barron LE. 1940. The presence of spirophetes in human gastric mucosa. Am J Dig Dis 7: 443445.

(23) Fukuda H, Saito D, Hayashi S, Hisai H, Ono H, Yoshida S, Oguro Y, Noda T, Sato T, Katoh M, Terada M, Sugimura T. 1995. Helicobacter pylori infection, serum pepsinogen level and gastric cancer: a case-control study in Japan. Jpn J Cancer Res 86: 64-71.

(24) Hopkins RJ, Girardi LS, Turney EA. 1996. Relationship between Helicobacter pylori eradication and reduced duodenal and gastric ulcer recurrence: a review. Gastroenterology 110: 1244-1252.

(25) van der Hulst RWM, Rauws EAJ, Koycu B, Keller JJ, Bruno MJ, Tussen JGP, Tytgat GNJ. 1997. Prevention of ulcer recurrence after eradication of Helicobacter pylori: a prospective long-term follow-up study. Gastroenterology 113: 1082-1086.

(26) Inouye H, Yamamoto I, Tanida N, Mikami J, Tamura K, Ohno T, Kano M, Shimoyama T. 1989. Campylobacter pylori in Japan: bacteriological feature and prevalence in healthy subjects and patients with gastroduodenal disorders. Gastroenterol Jpn 24: 494-504.

(27) International Agency for Research on Cancer, World Health Organization. 1994. Schistosomes, liver flukes and Helicobacter pylori. IARC Nonogr Eval Carcinog Risks Hum 61: 218-220.

(28) Kashiwara W, Ogawa T, Suda Y, Shimoyama T. Chemical structure and immunobiological activities of lipid A from Helicobacter pylori. Acta Med Hyogo (in press)

(29) Kato N, Watanabe K, Ueno K, Ito Y, Muto Y, Kato H, Sakai S. 1989. Gastric microflora in patients receiving $\mathrm{H}_{2-}$ blocker. Kansenshogaku Zasshi 63: 726-731.

(30) Kawaura A, Yamamoto I, Tanida N, Inouye H, Takahashi A, Tonokatsu Y, Sawada Y, Sawada K, Shimoyama T. 1991. Helicobacter pylori is not a co-carcinogen in Nmethyl- $\mathrm{N}^{\prime}$-nitro-N-nitrosoguanidine-induced rat gastric carcinogenesis. Tokushima J Exp Med 38: 71-75.

(31) Kim HY, Cho BD, Chang WK, Kim DJ, Kim YB, Park CK, Shin HS, Yoo JY. 1997. Helicobacter pylori infection and the risk of gastric cancer among the Korean population. J Gastroenterol Hepatol 12: 100-103.

(32) Kuipers EJ, Perez-Perez GI, Meuwissen SG, Blaser MJ. 1995. Helicobacter pylori and atrophic gastritis: importance of the cagA status. J Natl Cancer Inst 87: 1777-1780.

(33) Kuipers EJ, Uyterlinde AM, Pena AS, Roosendaal R, Pals G, Nelis GF, Festen HP, Meuwissen SG. 1995. Long-term sequelae of Helicobacter pylori gastritis. Lancet 345: 15251528.

(34) Kuniyasu H, Domen T, Hamamoto T, Yokozaki H, Yasui W, Tahara H, Tahara E. 1997. Expression of human telomerase RNA is an early event of stomach carcinogenesis. Jpn J Cancer Res 88: 103-107.
(35) Labenz J, Malfertheiner P. 1997. Helicobacter pylori in gastro-oesophageal reflux disease: causal agent, independent or protective factor? Gut 41: 277-280.

(36) Lam SK, Talley NJ. 1998. Report of the 1997 Asia Pacific Consensus Conference on the management of Helicobacter pylori infection. J Gastroenterol Hepatol 13: 1-12.

(37) Louw JA, Falck V, van Rensburg C, Zak J, Adams G, Marks IN. 1993. Distribution of Helicobacter pylori colonisation and associated gastric inflammatory changes: difference between patients with duodenal and gastric ulcers. J Clin Pathol 46: 754-756.

(38) Marchetti M, Arico B, Burroni D, Figura N, Rappuoli R, Ghiara P. 1995. Development of a mouse model of Helicobacter pylori infection that mimics human disease. Science 267: 1655-1658.

(39) Marshall BJ. 1983. Unidentified curved bacillus on gastric epithelium in active chronic gastritis. Lancet i: 1273-1275.

(40) Marshall BJ, Armstrong JA, McGechie DB, Glancy RJ. 1985. Attempt to fulfil Koch's postulates for pyloric Campylobacter. Med J Austr 142: 436-439.

(41) Maruta F, Sugiyama A, Ikeno T, Ishida K, Murakami M, Kawasaki S, Katsuyama T, Shimizu N, Tatematsu M. 1998. Promoter and co-initiater effects of Helicobacter pylori infection on MNU (N-methyl-N-nitrosourea)-induced stomach carcinogenesis in the Mongolian gerbil. Proceeding of the Annual Meeting of the Japanese Society of Helicobacter Research, p. 35.

(42) Matsukura N, Onda M, Kato S, Hasegawa H, Okawa K, Shirakawa T, Tokunaga A, Yamashita K, Hayashi A. 1997. Cytotoxin genes of Helicobacter pylori in chronic gastritis, gastroduodenal ulcer and gastric cancer: an age and gender matched case-control study. Jpn J Cancer Res 88: 532-536.

(43) Micots I, Augeron C, Laboisse CL, Muzeau F, Megraud F. 1993. Mucin exocytosis: a major target for Helicobacter pylori. J Clin Pathol 46: 241-245.

(44) Morris A, Nicholson G. 1987. Ingestion of Campylobacter pyloridis causes gastritis and raised fasting gastric $\mathrm{pH}$. Am J Gastroenterol 82: 192-199.

(45) Muotiala A, Helander IM, Pyhala L, Kosunen TU, Moran AP. 1992. Low biological activity of Helicobacter pylori lipopolysaccharide. Infect Immun 60: 1714-1716.

(46) Murakami M, Asagoe K, Dekigai H, Kusaka S, Saita H, Kita T. 1995. Products of neutrophil metabolism increase ammonia-induced gastric mucosal damage. Dig Dis Sci 40 268-273.

(47) Murakami M, Saita H, Teramura S, Dekigai H, Asagoe K, Kusaka S, Kita T. 1993. Gastric ammonia has a potent ulcerogenic action on the rat stomach. Gastroenterology 105: 1710-1715.

(48) National Institutes of Health Consensus Development Conference. 1994. Helicobacter pylori in peptic ulcer disease. JAMA 272: 65-69.

(49) Negrini R, Lisato L, Zanella I, Cavazzini L, Gullini S, Villanacci V, Poiesi C, Albertini A, Ghielmi S. 1991. Helicobacter pylori infection induces antibodies cross-reacting with human gastric mucosa. Gastroenterology 101: 437-445. 
(50) Nomura A, Stemmermann GN, Chyou P, Kato I, PerezPerez GI, Blaser MJ. 1991. Helicobacter pylori infection and gastric carcinoma in a population of Japanese-Americans in Hawaii. N Engl J Med 325: 1132-1136.

(51) Olbe L, Hamlet A, Dalenback J, Fandriks L. 1996. A mechanism by which Helicobacter pylori infection of the antrum contributes to the development of duodenal ulcer. Gastroenterology 110: 1386-1394.

(52) Parsonnet J. 1996. Helicobacter pylori in the stomach-A paradox unmasked. N Engl J Med 335: 278-280.

(53) Parsonnet J, Friedman GD, Orentreich N, Vogelman H. 1997. Risk for gastric cancer in people with CagA positive or CagA negative Helicobacter pylori infection. Gut 40 : 297-301.

(54) Parsonnet J, Friedman GD, Vandersteen DP, Chang Y, Vogelman JH, Orentreich N, Sibley RK. 1991. Helicobacter pylori infection and risk for gastric cancer. N Engl J Med 325: 1127-1131.

(55) Peek RM Jr, Moss SF, Tham KT, Perez-Perez GI, Wang S, Miller GG, Atherton JC, Holt PR, Blaser MJ. 1997. Helicobacter pylori cag $\mathrm{A}^{+}$strains and dissociation of gastric epithelial cell proliferation from apoptosis. J Natl Cancer Inst 89: 863-868.

(56) Rauws EA, Langenberg W, Houthoff HJ, Zanen HC, Tytgat GN. 1988. Campylobacter pyloridis-associated chronic active antral gastritis. A prospective study of its prevalence and the effects of antibacterial and antiulcer treatment. Gastroenterology 94: 33-40.

(57) Rokkas T, Papatheodorou G, Karameris A, Mavrogeorgis A, Kalogeropoulos N, Giannikos N. 1995. Helicobacter pylori infection and gastric juice vitamin $\mathrm{C}$ levels. Impact of eradication. Dig Dis Sci 40: 615-621.

(58) Salcedo JA, Al-Kawas F. 1998. Treatment of Helicobacter pylori infection. Arch Intern Med 158: 842-851.

(59) Sakagami T, Vella J, Dixon MF, ORourke J, Radcliff F, Sutton P, Shimoyama T, Beagley K, Lee A. 1997. The endotoxin of Helicobacter pylori is a modulator of host-dependent gastritis. Infect Immun 65: 3310-3316.

(60) Schlemper RJ, van der Werf SDJ, Vandenbroucke JP, Biemond I, Lamers CBHW. 1995. Seroepidemiology of gastritis in Japanese and Dutch working populations: evidence for the development of atrophic gastritis that is not related to Helicobacter pylori. Gut 37: 199-204.

(61) Segal ED, Lange C, Covacci A, Tompkins LS, Falkow S. 1997. Induction of host signal transduction pathways by Helicobacter pylori. Proc Natl Acad Sci USA 94: 75957599.

(62) Shimoyama T, Fukuda S, Tanaka M, Mikami T, Saito Y, Munakata A. 1997. High prevalence of the CagA-positive Helicobacter pylori strains in Japanese asymptomatic patients and gastric cancer patients. Scand J Gastroenterol 32: $465-468$.
(63) Sjotedt S, Levin P, Malmborg AS, Bergman U, Kager L. 1989. Septic complications in relation to factors influencing the gastric microflora in patients undergoing gastric surgery. J Hosp Infect 13: 191-197.

(64) Solomon H. 1896. Ueber das Spirillum des Saugtiermagens und sein Verhalten zu den Belegzellen. Zentralbl Bakteriol 19: 433-442.

(65) Steer HW. 1975. Ultrastructure of cell migration through the gastric epithelium and its relationship to bacteria. J Clin Pathol 28: 639-646.

(66) Suzuki M, Miura S, Suematsu M, Fukumura D, Kurose I, Suzuki H, Kai A, Kudoh Y, Ohashi M, Tsuchiya M. 1992. Helicobacter pylori-associated ammonia production enhances neutrophil-dependent gastric mucosal cell injury. Am J Physiol 263: G719-725.

(67) Tanida N, Sakagami T, Nakamura Y, Kawaura A, Hikasa Y, Shimoyama T. 1996. Helicobacter pylori and gastric cancer. Nihon Geka Gakkai Zasshi 97: 257-262.

(68) Tsujiai T, Sakagami T, Tanida N, Shimoyama T. 1995. Effect of Helicobacter pylori on N-methyl-N'-nitro-Nnitrosoguanidine induced gastroduodenal carcinogenesis in rats. The First Meeting on the Japanese Research Society for Helicobacter pylori Related Gastroduodenal Diseases, Tokyo, March 15, 1995.

(69) Tsujii M, Kawano S, Tsuji S, Nagano K, Ito T, Hayashi N, Fusamoto H, Kamada T, Tamura K. 1992. Ammonia: a possible promoter in Helicobacter pylori-related gastric carcinogenesis. Cancer Lett 65: 15-18.

(70) Uemura N, Mukai T, Okamoto S, Yamaguchi S, Mashiba H, Taniyama K, Sasaki N, Haruma K, Sumii K, Kajiyama G. 1997. Effect of Helicobacter pylori eradication on subsequent development of cancer after endoscopic resection of early gastric cancer. Cancer Epidemiol Biomarkers Prev 8: 639-642.

(71) Villako K, Kekki M, Tamm A, Tammur R, Savisaar E, Viirsalu V, Sipponen P. 1982. Epidemiology and dynamics of gastritis in a representative sample of an Estonin urban population. Scand J Gastroenterol 17: 601-607.

(72) Warren JR. 1983. Unidentified curved bacillus on gastric epithelium in active chronic gastritis. Lancet i: 1273 .

(73) Watanabe T, Tada M, Nagai H, Sasaki S, Nakao M. 1998. Helicobacter pylori infection induces gastric cancer in Mongolian gerbils. Gastroenterology 115: 642-648.

(74) Wu MS, Shun CT, Wang HP, Sheu JC, Lee WJ, Wang TH, Lin JT. 1997. Genetic alterations in gastric cancer: relation to histological subtypes, tumor stage, and Helicobacter pylori infection. Gastroenterology 112: 1457-1465.

(75) Wyatt JI, Rathbone BJ, Sobala GM, Shallcross T, Heatley RV, Axon ATR, Dixon MF. 1990. Gastric epithelium in the duodenum: its association with Helicobacter pylori and inflammation. J Clin Pathol 43: 981-986. 